http://e-journal.stit-islamic-village.ac.id/index.php/JM2PI

\title{
Metode Modelling dalam Pendidikan Karakter pada Anak (Analisis Surat Al Ahzab Ayat 21)
}

\author{
Devi Aini Nurwulandari \\ Program Studi Pendidikan Agama Islam, STIT Islamic Village Tangerang \\ Email: devi.nurwulandari@gmail.com
}

Received: September, 2020.

Accepted: Oktober, 2020.

Published: November, 2020

\begin{abstract}
The aim of this research is to analyze surah Al-Azhab verse 21 which contains of exemplary method. The exemplary method related to character building of children. The background of research is the lack of models or figures in exemplary, by the result children having exemplary crisis.

This research is library research, by using tafsir approach. The primer source of the research is tafsir Asy-Sya'rawi with the interpretation of Muhammad Mutawalli ashSha'rawi and also Tafseer Al- Mishbah by Muhammad Quraish Shihab.

The research result showed that exemplary method is effectively enough to shape children characters. Parents and teachers should be giving proper example due to children have imitating nature. Parents and teacher need to have traits such as Prophet Muhammad as contained in surah Al-Azhab verse 21
\end{abstract}

Keywords: Method, Modelling (exemplary),children character building.

\section{ABSTRAK}

Tujuan Penelitan ini adalab untuk menganalisis surat Al-Abzab ayat 21 yang berbicara tentang metode modelling. Metode modelling kemudian dikaitkan dengan pendidikan karakter pada anak. Latar belakang penelitian ini adalah karena jarang adanya model, ataupun contoh dalam keteladanan, sehingga anak-anak mengalami krisis keteladanan.

Penelitian ini merupakan penelitian Library Research, dengan menggunakan pendektan tafsir. Sumber primer penelitian ini adalah tafsir Asy-Sya'rawi karangan Mubammad Mutawalli AsySya'rawi dan tafsir Al-Mishbah karangan Muhammad Quraish Shihab

Hasil penelitian menunjukan bahwa metode modelling adalab salab satu metode yang cukup efek.tif dalam membentuk. karakter pada anak. Orang tua dan guru harus memberikan contoh yang baik karena anak-anak adalah makbluk yang senang meniru. Orang tua dan guru harus memiliki sifat-sifat seperti Rasulullah $S A W$ sebagaimana yang terkandung dalam surat $A$ lAhrab ayat 21. 
Kata kunci : metode, modelling, pendidikan karakter.

\section{PENDAHULUAN}

Pada dasarnya manusia sangat mengistimewakan dan mengutamakan Rasulullah SAW dan mempunyai keinginan ataupun sangat memerlukan sosok teladan dan panutan seperti Rasulullah SAW yang selalu mengarahkan kepada hal-hal yang baik ataupun kepada jalan yang lurus dan benar. Menjadikan perumpamaan yang dinamis yaitu suri tauladan untuk menyampaikan syariat-syariat Allah SWT. Karena hal itu Allah SWT mengutus Rasul-Rasulnya untuk menjelaskan berbagai syariat-syariat melalui contoh keteladanan. Akan tetapi hari ini jarang ada manusia yang seperti Rasulallah SAW yang mempunyai suri tauladan atau contoh yang baik.(alNahlawi, 1989)

Dalam kehidupan sehari-hari baik di rumah ataupun di sekolah dapat menyaksikan tindakan dalam hal keagamaan seperti tindakan yang Islami yang dilakukan oleh anak-anak pada dasarnya mereka melakukan itu dari hal meniru, baik berupa pembiasaan sehari-hari ataupun pengajaran yang dilaksanakan dengan sungguh-sungguh. Contohnya dalam kehidupan seharihari mereka melaksanakan, ataupun mengerjakan hasil dan melihat perbuatan di yang ada di lingkungannya baik di rumah ataupun di sekolah dan di lingkungan masyarakat sekitar. Para ahli ilmu jiwa menanggapi bahwa dalam segala hal anak merupakan peniru yang ulung atau berpengalaman. Sifat meniru ini merupakan metode yang positif dan tidak ada unsur negatif dalam pendidikan keagamaan pada anak.(ramayulis, 2010)

Dalam sejarah hidupnya Rasulullah SAW selalu memberikan contoh teladan yang baik bukan yang buruk kepada para Sahabat-Sahabatnya melalui contoh keteladanan, baik dari segi ucapan atau perkataan dan perbuatan atau tindakan beliau, karena terpujinya akhlak baik beliau, beliau mendapatkan julukan Al-Amin yang artinya dapat dipercaya, dan itu diakui oleh kawan seperti orang-orang yang mencintai Rasulullah SAW dan lawan beliau seperti musuh-musuhnya atau orang-orang yang tidak menyukai Rasulullah SAW. Metode Modelling yang dicontohkan Rasulullah SAW merupakan asal mula terbentuknya pendekatan atau metode Modelling dalam pendidikan Islam yang saat ini masih nyata dan betul-betul ada dan akan terjadi. Metode ini bisa masuk wilayah pendidikan formal seperti disekolah dan pendidikan informal (keluarga) maupun non-formal atau pendidikan yang tidak resmi.(Mustofa, 2019)

Modelling juga dapat ditunjukkan dalam prilaku dan sikap yang baik bukan yang buruk oleh pendidik dan tenaga kependidikan dalam memberikan dan mengaplikasikan di kehidupan sehari-harinya dengan contoh yang baik

JM2PI: Jurnal Mediakarya Mahasiswa Pendidikan Islam 
sehingga diharapkan menjadi panutan bagi anak didik. Pengaplikasian berbagai contoh baik dalam keteladanan merupakan langkah awal pembiasaan. Jika pendidik dan tenaga kependidikan ingin anak didik berprilaku dan bersikap sesuai dengan nilai- nilai karakter, maka pendidik dan tenaga kependidikan harus menjadi orang yang pertama dan utama dalam memberikan contoh.

Pertama dan utama dalam memberikan, menyampaikan, serta mengaplikasikan contoh yang baik dengan cara berprilaku dan bersikap sesuai dengan nilai-nilai baik tersebut. Contohnya datang ke sekolah tepat waktu atau on time, berpakaian rapi, bekerja keras dalam segala hal, bertutur kata sopan dan santun, memberikan kasih sayang terhadap orang yang lebih tua ataupun muda dan sesama manusia, memberikan perhatian terhadap anak didik, jujur dalam berkata dan berbicara, dan selalu menjaga kebersihan baik untuk dirinya sendiri, di rumah, di sekolah dan di lingkungan masyarakat.(Gunawan heri, 2014)

Keteladanan guru adalah suatu yang wajib ditiru, yang ditiru oleh anak didik di lingkungan sekolah ataupun di dalam kelas. Guru disini disebut orang yang diteladani. Menjadi teladan merupakan kewajiban dari seorang guru atau tenaga kependidikan, sehingga menjadi guru berarti menerima semua tanggung jawab untuk menjadi teladan. Tentu saja hal pribadi dan apa yang dilakukan guru akan mendapat sorotan oleh anak didik dan orang yang di sekitar lingkungannya, maka dari itu guru harus menunjukan teladan yang terbaik dan \moral yang sempurna sehingga dapat memberikan contoh yang baik.(Munir, 2006)

Modelling juga dapat ditunjukkan dalam prilaku dan sikap yang baik bukan yang buruk oleh pendidik dan tenaga kependidikan dalam memberikan dan mengaplikasikan di kehidupan sehari-harinya dengan contoh yang baik sehingga diharapkan menjadi panutan bagi anak didik. Pengaplikasian berbagai contoh baik dalam keteladanan merupakan langkah awal pembiasaan. Jika pendidik dan tenaga kependidikan ingin anak didik berprilaku dan bersikap sesuai dengan nilai- nilai karakter, maka pendidik dan tenaga kependidikan harus menjadi orang yang pertama dan utama dalam memberikan contoh.

Pertama dan utama dalam memberikan, menyampaikan, serta mengaplikasikan contoh yang baik dengan cara berprilaku dan bersikap sesuai dengan nilai-nilai baik tersebut. Contohnya datang ke sekolah tepat waktu atau on time, berpakaian rapi, bekerja keras dalam segala hal, bertutur kata sopan dan santun, memberikan kasih sayang terhadap orang yang lebih tua ataupun muda dan sesama manusia, memberikan perhatian terhadap anak didik, jujur dalam berkata dan berbicara, dan selalu menjaga kebersihan baik 
untuk dirinya sendiri, di rumah, di sekolah dan di lingkungan masyarakat.(Gunawan heri, 2014)

Keteladanan guru adalah suatu yang wajib ditiru, yang ditiru oleh anak didik di lingkungan sekolah ataupun di dalam kelas. Guru disini disebut orang yang diteladani. Menjadi teladan merupakan kewajiban dari seorang guru atau tenaga kependidikan, sehingga menjadi guru berarti menerima semua tanggung jawab untuk menjadi teladan. Tentu saja hal pribadi dan apa yang dilakukan guru akan mendapat sorotan oleh anak didik dan orang yang di sekitar lingkungannya, maka dari itu guru harus menunjukan teladan yang terbaik dan \moral yang sempurna sehingga dapat memberikan contoh yang baik.(Munir, 2006)

\section{METODE}

Penelitian ini merupakan penelitian Library Research, dengan menggunakan pendektan tafsir. Sumber primer penelitian ini adalah tafsir Asy-Sya'rawi karangan Muhammad Mutawalli Asy- Sya'rawi dan tafsir Al-Mishbah karangan Muhammad Quraish Shihab.

\section{HASIL DAN PEMBAHASAN}

\section{Analisis Kandungan Tafsir QS. Al-Ahzab Ayat 21 Perspektif 'Tafsir Pemikiran Muhammad Mutawalli Asy-Sya'rawi.}

Imam Sya'rawi atau yang mempunyai nama asli Muhammad Mutawalli Asy-Sya'rawi lahir di kota Mesir tepatnya di Desa Daqadus yang merupakan perkampungan sederhana yang berada di Mait Gamair kepulauan Daqahlia, beliau lahir pada hari ahad tanggal 17 Rabi'ul Akhir, Tahun $1329 \mathrm{H}$ atau 16 april $1911 \mathrm{M}$. Wafat pada rabu tanggal 17 juni 1998 M dengan usia 87 tahun dan dimakamkan di kota Mesir.(Muhammad, 2006)

Imam Sya'rawi memulai kariernya sebagai pengajar di berbagai ma'had seperti Ma'had Al-Azhar Thatha, Ma'bad Alexandria, Ma'bad Zaqaziq. Beliau juga pernah mengajar di Universitas Malik Abdul Aziz di kota Mekkah Saudi Arabia sebagai dosen pada Fakultas Syari'ah jurusan tafsir hadits Selama lebih kurang 9 tahun. Beliau pernah menjabat sebagai wakil kepala sekolah di Al-Azhar Mesir dan Direktur dalam pengembangan dakwah islam pada tahun 1961 M di Departemen Wakaf. Nama Imam Sya'rawi mulai terdengar di berbagai kalangan pada saat beliau mengisi salahsatu acara sebagai da'i di stasiun televisi yaitu Nur' ala an-Nur pada tahun 1973. Muhammad Mutawalli Al-Sya'rawi atau imam Asy-Sya'rawi merupakan seorang mufasir dan cendekiawan muslim dengan pemikiran- 
pemikiran yang brilliant, genius, cerdas, pintar, dan yang termuat dalam kitab tafsir karangan beliau yang bertemakan pembaharuan pembentukan karakter pada anak. Beliau merupakan seorang ahli tafsir Al-Qur'an dan imam pada masa modern dan saat ini. Beliau sangat memperhatikan konsep dalam pembentukan karakter pada anak yang dipengaruhi oleh suri tauladan yang baik. Pemikiran Imam Sya'rawi tentang suri tauladan yang menjadi titik pembentukan karakter anak ini tertuang pada tafsir $\mathrm{Al}-$ Qur'an di dalam surat Al-Ahzab ayat 21. (Idit, 2014) ayat 21:

Hal ini sesuai dengan Firman Allah SWT, dalam surat Al-ahzab

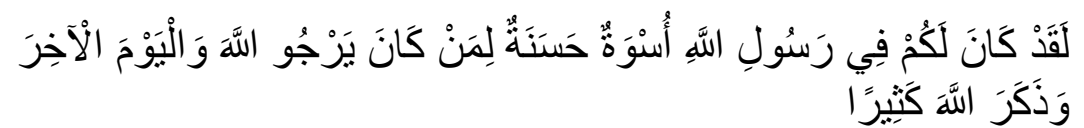

"Sesunggubnya telab ada pada diri Rasulullah $S A W$ itu suri tauladan yang baik bagimu yaitu bagi orang-orang yang mengharap rabmat Allah SWT. Dan kedatangan hari kiamat dan dia banyak mengingat Allah SWT." (Departemen Agama Republik Indonesia, 2012)

Dalam Al-Qur'an surat Al-Ahzab ayat 21 yang menjelaskan tentang Rasulullah SAW. sebagai suri tauladan untuk manusia seluruhnya. Ayat ini banyak ditafsirkan oleh para mufasir yang kemudian dijadikan sebuah pedoman dalam usaha memperbaiki perilaku manusia. Sikap seorang muslim dan muslimah yang baik akan menjadi ideal maka harus bersumber dengan ajaran agama Islam yang dibawa oleh Nabi Muhammad SAW adalah sumber yang menjadi mata air yang mengalir seluruh kebaikan manusia.tentu saja banyak orang lain yang dapat dijadikan pemimpin, panutan, dan pembimbing. Namun kebaikan dan kebenaran hanyalah fatamorgana jika ia tidak menghulu pada sang sumber" kebenaran insani, yakni Nabi Muhammad SAW . Dan di dalam kitabnya Imam Sya'rawi memaparkan bahwa Allah SWT memuji kepada Nabi Muhammad SAW. Beliau memaparkan bahwa teladan insani yang terbaik, termulia, dan tertinggi adalah Muhammad bin Abdullah Rasulullah SAW. (Asy-Sya'rawi, 1999)

Berdasarkan ayat diatas sangat jelas disebutkan kata uswab dan hasanah yang artinya teladan yang baik. Maka dapat disimpulkan bahwa konsep keteladanan sudah hadir dari zaman dulu yang diberikan oleh Allah SWT dengan cara nya yang indah yaitu mengutus para Rasul, terutama Nabi Muhammad SAW. Tujuannya adalah untuk menjadi panutan untuk umat manusia yang beragama Islam. Begitu halnya dengan 
seorang guru harus menjadi panutan atau teladan yang baik untuk anak didiknya, baik dalam segi pelajaran dan aspek lainnya.

Asy-Sya'rawi (1999) berpendapat bahwa :

Kata uswah menurut Imam Sya'rawi memiliki arti bahwa Rasulullah SAW adalah contoh, model, dan seorang yang behavioris didalam segala aspek kehidupan. Rasulullah SAW sebagai seorang mubalig atau seorang yang selalu menyampaikan ayat-ayat Allah untuk segala menjaga lisan, perilaku dan perbuatan manusia di dalam segala aspek kehidupan. Sehingga menurut Imam Sya'rawi pantaslah Rasulullah SAW disebut sebagai Uswah suluk.(Asy-Sya'rawi, 1999)

Hal ini dikuatkan dengan perkataan istri, Rasulullah SAW yaitu Sayyidah Aisyah RA. Beliau berkata : "Kana Khuluqubul Qur'an"

Atas dasar inilah, maka islam memanggil agar orang- orang orang islam mempercantik diri dengan akhlak yang baik

Serta ditumbuhkan dan dikembangkan di dalam jiwanya agar imannya baik. Sebab iman seseorang sesuai pada keutamaan jiwanya sebagaimana kualitas agama Islammnya pun tergantung pada kebaikan akhlaknya yang baik. Allah SW'T memuji nabi Muhammad SAW karena memiliki akhlak yang baik, bagus, dan tinggi.

Allah SWT berfirman di dalam AL-Qur'an surat Al-Qalam ayat 4:

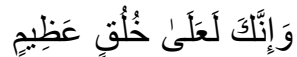

Allah juga berfirman di dalam Al-Qur'an surat Ali-Imran ayat 133134:

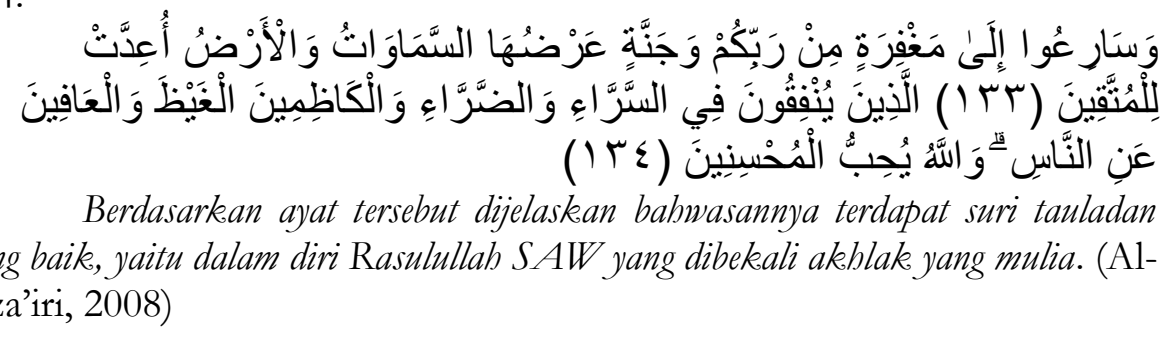

Hal ini membawakan hasil yang baik dapat memberikan perhatian ataupun pengertian tentang pentingnya pembentukan karakter pada anak dalam kehidupan manusia agar mendapatkan akhlak yang baik. (Zainudin, 2013)

Sehingga dengan akhlak yang baik manusia dapat mengutamakan kebaikan, kebeneran, dan kesenangan. Kemudian dilatih dan dibentuk untuk mencintai yang terpuji dan membenci serta menjauhi yang tercela, contohnya maka sifat-sifat tersebut dapat menjadi karakter bagi jiwa anak, 
sehingga perbuatan-perbuatan positif dan sikap-sikap terpuji ini adalah apa yang dikenal dengan akhlak anak yang baik. (Al-Jaza'iri, 2008)

Akhlak adalah tata cara berprilaku manusia yang sesuai dengan norma-norma yang baik dan adanya aturan yang baik yang muncul dari adat istiadat, Negara, dan agama. Akhlak agama adalah sikap dengan nilainilai yang bersifat Islami dan aturan agama, yang di anggap baik ataupun yang disukai,disetujui oleh agama dan menurut agama dan yang buruk adalah apa yang dianggap buruk ataupun yang tidak disukai oleh agama. Keluarga adalah salah satu nilai dan norma agama yang pertama kali ditemukan oleh anak, karena orangtuanya lah yang mengIslamkannya. Keluarga sangat berkewajaiban mengajarkan akhlak kepada anak, seperti adanya kebenaran, kejujuran, keikhlasan, kesabaran, kasih sayang, pemurah, penyayang, pemaaf, penolong, bersahaja dan sebagainya.

Hal-hal yang harus ditempuh orang tua dalam pembentukan karakter pada anak adalah dengan memberikan contoh keteladanan yang baik bukan yang buruk kepada anak dengan berpegang teguh kepada akhlak yang baik dan mulia seperti Rasulullah SAW. Maka dari itu, dalam hal pembentukan karakter pribadi pada anak baik dari agama, sosial, hal yang pertama harus dilakukan oleh orang tuanya adalah dengan memberikan metode keteladanan yang baik kepada anak. (Padil, 2010). Agar keluarganya dapat menjalankan tugasnya, maka orang tua harus menunjukkan melalui contoh yang baik, budi bahasa dan menetapkan akidah Islam. Ada landasan moral dan nilai yang dapat dijadikan oleh keluarga muslim dan muslimah sebagai landasan mendorong dalam proses pembentukan karakter pribadi pada anak.(Asy-Sya’rawi, 1999)

Asy- Sya'rawi (1999) berpendapat bahwa:

"Konsep teladan dalam pembentukan karakter pribadi anak dengan landasan akhlak mulia Rasulullaah SAW adalah konsep yang diajarkan Rasulullah SAW bagi orang-orang yang selalu mengingat Allah SWT dalam Hidupnya. Mengenai pembentukan karakter pribadi anak, Imam Sya'rawi berkata "Yang terpenting dalam membentuk pribadi anak adalah suri teladan. Seandainya didapatkan suri teladan yang baik, seorang anak akan menjadikannya sebagai contoh. Maka seorang anak harus dicermati dengan baik, dan di sana terdapat perbedaan antara mengajari anak dan membentuknya."(Asy-Sya'rawi, 1999)

Asy- Sya'rawi (1999) berpendapat bahwa:

"Seorang anak, jika tidak bergerak kemampuannya dan bersiap untuk menerima dengan lapang dada dan menampung yang ada disekitarnya. Maka orangtua mempunyai tugas besar dalam 
pengasuhannya. Hal ini terjadi apabila tidak siap telinganya untuk mendengar, kedua matanya untuk melihat, hidung nya untuk mencium,dan ujung-ujung jarinya untuk menyentuh, kita wajib menjaga seluruh kemampuannya dengan tingkah laku orangtua yang membentuk bersamanya dan di depannya. Oleh karena itu orang tua harus menjaga telinganya dari setiap perkataan yang jelek dan menjaga matanya dari setiap pemandangan yang merusak. Imam Sya'rawi menambahkan bahwa orangtua harus membentuk karakter anak-anak dengan konsep yang berbeda yaitu konsep islam. Apabila anak melihat orangtua mengerjakan yang demikian itu, anak akan mengikutinya dengan mudah, begitu pula hal yang lainnya. Tapi jika anak itu tidak mengambil pelajaran dalam hal ini, tindakan lebih penting daripada omongan belaka.(Asy-Sya'rawi, 1999). Sehingga teladan merupakan metode terbaik dalam pendidikan akhlak dan karakter anak, karena sifat manusia adalah menirukan apa yang mereka lihat dan mereka dengar pada massa kanak-kanak dan masa anak usia dini.

Dalam fase anak dini pada kehidupannya, anak banyak belajar tentang berbagai kebiasaan dan tingkah laku melalui peniruan atau peneladanan terhadap kebiasaan dan tingkah laku kedua orangtuanya. Pada dasarnya hal ini karena bertolak pada tabiat manusia yang berminat untuk meniru dan belajar banyak dari tingkah laku anak melalui peniruan, maka dari itu teladan yang baik sangat terpenting dalam pembentukan karakter pada anak. Nabi Muhammad SAW. Sendiri menjadi teladan bagi para sahabat, istri, anak, cucu beliau. (Rahman, 2005) Dari beliau mereka belajar bagaimana mereka melaksanakan berbagai macam ibadah . selain aturan-aturan ibadah, para sahabat juga belajar dari beliau tentang tingkah laku yang baik, akhlak yang tinggi luhur dan tata karma pergaulan. (AsySya'rawi, 1999) Melalui teladan yang baik, manusia belajar kebiasaan yang baik dan akhlak yang mulia. Sebaliknya melalui teladan yang buruk, manusia pun akan belajar kebiasaan buruk dan akhlak yang tercela.

\section{Analisis Kandungan Tafsir QS. Al-Ahzab Ayat 21 Perspektif Tafsir Al-Mishbah Pemikiran Muhammad Quraish Shihab.}

Muhammad Quraish Shihab beliau lahir tanggal 16 Februari 1944 di Rapang, Sulawesi Selatan. beliau berada dari keluarga keturunan Arab yang terpelajar. Ayahnya, Prof. KH. Abdurrahman Shihab adalah seorang ulama dan guru besar dalam bidang tafsir. Ayah Shihab, sering mengajak Quraish Shihab bersama saudara yang lainnya untuk bercakap-cakap dan bermain-main bersama dan sambil memberikan wejangan atau nasihat keagamaan yang islami. Dari sinilah mulai adanya benih cinta dari 
Muhammad Quraish Shihab terhadap studi Al-Qu'ran. Sejak Kecil sekitar umur 6 atau 7 tahun, beliau harus sudah ikut mendengarkan ayahnya mengajar Al-Qur'an. Ketika itu ayahnya, selain mengajarkan cara membaca Al-Qur'an, juga menceritakan kisah-kisah Nabi yang diambil dari Al-Qur'an. Saat saat itulah muncul kecintaan beliau terhadap AlQur'an mulai tumbuh dan yakin terhadap cintanya itu tulus terhadap $\mathrm{Al}-$ Qur'an.(Shihab, Quraish, 1992) Riwayat pendidikannya dimulai dengan pendidikan dasarnya (SD-SLTP) di Ujung Padang, lalu beliau melanjutkan pendidikan menengahnya di Malang (1956-1958) sambil belajar menjadi santri di Pondok Pesantren Darul Hadis al-Faqhiyyah, Malang.(Nata, 2005) Pada tahun 1958, beliau berangkat ke Kairo Mesir untuk melanjutkan studinya yang bermodalkan dengan bekal ilmu yang beliau punya.

Quraish Shihab, (2002) berpendapat bahwa:

Dalam redaksi lain yang terkait dengan surat Al-Ahzab ayat 21 ini dapat dijelaskan secara detail dan singkat tentang asbabun nuzul surat $\mathrm{Al}$ Ahzab dapat diketahui bahwa surat ini merupakan surat yang ke 33 sebagaimana terdapat dalam Al-Qur'an. Jumlah ayat dalam surat ini dikategorikan sebagai surat madaniyah, yang diturunkan sesudah surat $\mathrm{Al}$ Imran. Penanaman surat ini sebagai surat Al Ahzab yang dapat dipahami dengan "golongan-golongaan yang bersekutu" mulai dari ayat 9 sampai 27 ayat ini semuanya berkaitan dengan peperangan Al-Ahzab, yakni peperangan yang dilancarkan oleh kaum yahudi dimana mereka bersekutu dengan kaum munafik serta orang-orang musyrik terhadap orang-orang mukmin di Madinah.dalam kaitan ini, Muhammad Quraish Shihab dalam tafsirnya menyatakan bahwa: surat Al-Ahzab adalah surat madaniah, sehingga para ulama muawafaqah tentang hal itu.karena surah ini diturunkan tepatnya pada akhir tahun ke 4 hijriah yaitu tahun terjadinya perang Al-Ahzab atau gazwat. Selain itu ada juga yang dinamakan perang khandaq hal ini di karenakan berdasarkan adanya usulan dari salah satu sahabat Rasulullah SAW yaitu Salman Al Farisi, bersama juga dengan para sahabat Rasulullah SAW yaitu Salman Al-Farisi, bersama juga dengan para sahabat beliau menggalu parit (khandaq) menuju arah utara kota Madinah, tempat tersebut yang besar kemungkinan menjadi arah serangan musuh (musyrikin). peristiwa ini terjadi pada bulan syawal tahun ke V Hijriah. bahwa:

Dalam redaksi lain, Muhammad Quraish Shihab yang menyatakan

"kasus pemilihan lokasi dalam peperangan badar, merupakan salah satu contoh yang sering diketengahkan, walaupun hadisnya dhaif dan lemah, yakni ketika sahabat Nabi SAW, Al- Khubbab Ibnu Al-Munzir, mengusulkan kepada Nabi agar memilih lokasi selain beliau tetapkan, 
setelah sahabat tadi mengetahui dari Nabi sendiri bahwa pemilihan tersebut berdasarkan pertimbangan nalar beliau dan strategi perang. Usul tersebut diterima baik. Oleh Nabi SAW. Karena memang ternyata lebih baik dan benar.(Shihab \& Quraish, 2002)

Jadi dapat disimpulkan tujuan asbabun nuzulnya surat Al-Ahzab ayat 21 adalah untuk menginformasikan sebuah kabar yang gembira atau berita yang baik dan hiburan kepada Rasulullah SAW beserta untuk umat muslim dan muslimah saat menghadapi berbagai cobaan, siksaan dan celaan yang diserang oleh musuh-musuh Allah SWT. Dimana ujian tersebut tidak hanya menimpa mereka saja namun juga para Rasulullah SAW dan Nabi sebelum mereka. Sebagaimana dalam surat ini juga untuk meyakinkan dan memperkuat dalil akan kebenaran risalah yang dibenarkan oleh Rasulullah SAW.

Muhammad Quraish Shihab berpendapat kata laqad merupakan tuduhan, Muhammad Quraish Shihab berpendapat dari Allah SWT. kepada orang-orang munafik yang mengaku memeluk Islam, tetapi tidak menggambarkan serta tidak mengaplikasikan ajaran Islam di kehidupan sehari-hari. Seakan-akan ayat itu mengatakan: "Kamu telah melakukan aneka kedurhakaan, padahal sesungguhnya di tengah kamu semua ada Nabi Muhammad SAW yang wajib kamu teladani".

Kalimat liman kana yarju Allah wa al-yaum al-akbir artinya bagi orang yang mengharap Allah dan hari Kiamat, berfungsi untuk menjelaskan sifat orang-orang yang mestinya meneladani Rasul SAW. Memang, untuk meneladani Rasul SAW. Secara sempurna diperlukan kedua hal yang disebut ayat di atas. Demikian juga dengan zikir kepada Allah SWT. dan selalu mengingat-Nya.

Shihab \& Quraish (2002) berpendapat bahwa :

"Kata uswah atau iswah berarti keteladanan atau teladanan. Pakar tafsir yang dikutip M. Quraish Shihab dalam tafsirnya mengatakan AzZamakhsyari ketika menafsirkan ayat di atas, mengemukakan dua kemungkinan tentang maksud keteladanan yang terdapat pada diri Rasul SAW itu. Pertama, dalam arti kepribadian beliau secara totalitas adalah keteladanan. Kedua, dalam arti terdapat dalam kepribadian Rasul SAW. halhal yang patut diteladani. Pendapat pertama lebih kuat dan merupakan pilihan banyak ulama tentang keteladanan."

Kata ( $i$ rasulillah berfungsi "mengangkat" dari diri Rasul atau kepribadian Rasul satu sifat yang wajib diteladani. Dalam konteks Perang 
Khandaq ini, banyak sekali sifat, sikap, ataupun perbuatan Rasul SAW yang wajib diteladani. Antara lain keterlibatan beliau secara langsung dalam kegiatan perang, bahkan menggali parit. Juga dalam membakar semangat dan mengutamakan keagungan terhadap Allah SWT baik dalam keadaan suka dan duka, haus dan dahaga yang dialami oleh seluruh pasukan kaum muslimin.

Ayat ini, berbicara dalam konteks perang khandaq, tetapi membahas tentang kewajiban atau anjuran dalam meneladani Rasulullah SAW. Ini karena Allah SWT telah menunjukan seseorang yang sangat istimewa ini untuk menjadi teladan bagi semua manusia dan seluruh alam. Dalam sabda Rasulullah SAW. "Addabani Rabbi fa absana ta'dibi" artinya Tuhanku."mendidikku, maka sungguh baik hasil pendidikanku (HR. Ibnu Mas'ud dalam al-Jami' al-Shaqhir)

Quraish Shihab mengutip bahwa Pakar tafsir dan hukum, AlQurtubi mengungkapkan :

"Soal-soal agama Islam keteladanan merupakan kewajiban dan keharusan, tetapi soal-soal keduniaan maka ia merupakan anjuran ataupun hukumnya sunnah tidak boleh cinta terhadap dunia. Dalam soal keagamaan, Rasul SAW wajib diteladani selama tidak ada bukti yang menunjukkan bahwa ia adalah anjuran. Sementara ulama berpendapat bahwa dalam persoalan-soalan keduniawian, Rasul SAW telah menyerahkan sepenuhnya kepada para pakar di bidang masing-masing, sehingga keteladanan terhadap Rasulullah SAW yang dibicarakan dalam ayat ini bukanlah dalam hal-hal yang berkaitan dengan soal-soal keduniaan. Ketika Rasul SAW menyampaikan bahwa pohon kurma tidak perlu "dikawinkan" untuk membuahkannya dan ternyata bahwa informasi Rasul SAW tidak terbukti di kalangan sekian banyak sahabat, Rasul SAW. menyampaikan bahwa "Apa yang ku sampaikan menyangkut ajaran agama, maka terimalah, sedang kamu lebih tahu persoalan keduniaan kamu".

Sementara pakar agama yang lain menolak pendapat di atas, AlBaqa'i misalnya dalam menafsirkan Q.S Al-Anfal [8]:24-25 mengutip pendapat Al-Harrali yang berbicara tentang hadis di atas, bahwa pernyataan Rasul SAW itu ditunjukkan kepada mereka yang tidak sabar, tetapi yang bersabar mengikuti petunjuk itu, pembuktiannya setelah berlalu tiga tahun, bahwa pohon kurma mereka (yang tidak dikawinkan sebagaimana petunjuk Rasul SAW tersebut) justru menghasilkan buah yang jauh lebih baik dibandingkan dengan buah pohon kurma yang dikawinkan. 
Terlepas dari salah atau benar tidaknya riwayat yang dikutip AlBaqa'I di atas, namun pada hakikatnya terdapat hadis-hadis yang menunjukkan bahwa para sahabat sendiri, telah memilih dan memilah ucapan dan perbuatan Rasul SAW. Ada yang mereka rasakan wajib dikuti dan ada pula yang tidak harus diikuti. Kasus pemilihan lokasi dalam peperangan Badr, merupakan salah satu contoh yang sering diketengahkan, walaupun hadisnya dinilai lemah atau dha'if yaitu ketika seorang sahabat Rasul Al-Khubbab Ibn Al-Munzir, mengusulkan kepada Rasul SAW agar memilih lokasi tempat selain lokasi tempat yang telah ditentukan Rasul SAW, setelah sahabat tadi mengetahui dari Rasul SAW sendiri bahwa pemilihan tersebut berdasarkan pertimbangan dengan daya nalar Rasul SAW dan strategi perang. Usul tersebut diterima dengan baik oleh Rasul SAW karena dianggap lebih baik.

Abqariyat, Muhammad, (1942) berpendapat bahwa

"Abbas Mahmud Al-'Aqqad dalam bukunya Abqariyat Muhammad menjelaskan ada empat tipe manusia, yaitu pemikir, pekerja, seniman, dan jiwanya larut di dalam ibadah. Jarang ditemukan satu pribadi yang berkumpul dalam dirinya dan dalam tingkat yang tinggi dua dari keempat kecendrungan atau tipe tersebut, dan mustahil keempatnya berkumpul pada diri seseorang. Namun yang mempelajari pribadi Rasulullah SAW.akan menemukan bahwa keempatnya bergabung dalam peringkatnya yang tertinggi pada kepribadian Rasul SAW. Berkumpulnya keempat tipe manusia itu dalam kepribadian Rasul SAW, dimaksudkan agar seluruh manusia meneladani sifat-sifat terpuji yang ada pada diri Rasul SAW.

Imam Al-Qarafi, adalah seorang ulama yang pertama yang menegaskan pemilahan secara rinci menyangkut ucapan atau sikap Rasulullah SAW, agar dapat berperan sebagai Rasul SAW. Adanya Mufti atau Hakim Agung atau Pemimpin masyarakat, dan bisa juga menjadi seorang manusia, yang memiliki kekhususan yang terlihat beda dari manusia-manusia lain. Dalam kedudukannya sebagai Rasul SAW.:

1) Nabi dan Rasul SAW maka ucapan dan sikapnya pasti benar, karena itu bersumber langsung dari Allah SWT. atau merupakan penjelasan tentang yang maksud Allah SWT.

2) Mufti, fatwa-fatwa Rasul SAW memiliki kedudukan yang sangat tinggi sesuai dengan teks-teks keagamaan, karena Rasul SAW langsung diberi kekuasaan oleh Allah SWT. Anggapan ini diperkuat dalam surat An-Nahl ayat 44 :

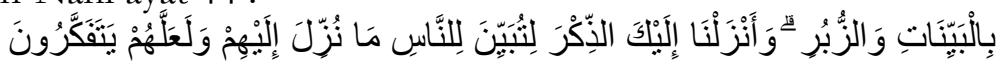


"Mereka Kami utus dengan membawa keterangan-keterangan (mukjizat) dan kitab-kitab. Dan Kami turunkan Adz Drikr (Al-Qur'an) kepadamu, agar kamu (Mubammad) menerangkan kepada manusia apa yang telah diturunkan kepada mereka dan agar mereka memikirkan"(Q.S. anNabl:44)

3) Rasul SAW sebagai hakim, maka ketetapan hukum Rasulullah SAW yang putuskan secara formal dan pasti benar, tetapi secara material ada kalanya keliru akibat kemampuan salah satu pihak yang berselisih menyembunyikan kebenaran atau kemampuanya berdalih dan mengajukan berita bohong dan palsu.

4) Pemimpin masyarakat, maka tentu saja petunjuk-petunjuk Rasul SAW. Dalam hal kemasyarakatan disesuaikan dengan kondisi masyarakat dan perkembangannya, sehingga tidak menutup kemungkinan lahirnya perbedaan tuntunan kemasyarakatan antara satu masyarakat dengan masyarakat lain, bahkan masyarakat yang sama dengan kurun waktu yang berbeda Rasul SAW sendiri tidak jarang memberi petunjuk yang berbeda untuk sekian banyak orang yang berbeda dalam menyesuaikan dengan masing-masing mereka. Tidak jarang pula ada ketetapan bagi masyarakatnya yang Rasul SAW ubah akibat perkembangan masyarakat itu, misalnya dalam sabda Rasul "saya pernah melarang kalian menziarahi kubur, kini silahkan menziarahinya" izin ini, disebabkan karena kondisi masyarakat telah berbeda dengan kondisi mereka saat larangan itu ditetapkan termasuk dalam kategori dalam kategori, hal-hal yang berkaitan dengan budaya masyarakat.

5) Selaku pribadi dalam hal ini dibagi menjadi dua kategori

a) Rasul SAW mempunyai kekhususan yang tidak boleh atau tidak harus diteladani, karena kekhususan tersebut berhubungan dengan fungsinya menjadi Rasulullah SAW. Contoh Seperti larangan menerima zakat untuknya.

b) Seseorang yang memiliki sifat-sifat yang siddiq, amanah, fhatanah dan tabligh.

c) Sebagai manusia terlepas dari kerasulannya memiliki selera.

\section{Keteladanan Rasulullah SAW}

Konsep Rasulullah SAW Dalam Mendidik Anak

Pada masa yang sedikit (di banding masa Nabi-Nabi sebelumnya) Rasulullah SAW sangatlah sukses dalam mendidik anak-anak dan keluarganya di rumah, dan juga mendidik para sahabat dan kaumnya saat zaman dulu kala. Sistim pendidikan yang di aplikasikan oleh Rasulullah SAW adalah sistim pendidikan yang bersumber dari wahyu Allah SWT, 
sehingga dapat mencetak pribadi yang sangat mulia. Padahal pada masa itu, masyarakat tempat tinggal Rasulullah SAW di utus adalah masyarakat jahiliyah atau pada masa kebodohan yang tidak Mampu memahami norma-norma sama sekali seperti norma agama.(hisyam, n.d.) Dengan keseriusan dan sikap concern (perhatian) beliau dalam dunia pendidikan, tentunya tidak mengherankan jika dalam waktu yang relative singkat Rasulullah SAW mampu meraih kesuksesan yang gemilang dalam mendidik dan mengajar umat manusia. Kunci kesuksesan pengajaran beliau dapat bersinar dan cantik terletak pada kepandaian dan kapabilitas beliau dalam menciptakan suasana pembelajaran yang sinergis, serta membebaskan mereka dari kebodohan dan menganjurkan mereka untuk senantiasa bersikap tegas dan konsisten dalam merealisasikan tujuantujuan pendidikan.(fatah, 2009) Rasulullah SAW mensunnahkan agar para orang tua mengajarkan anaknya untuk mengendarai kuda, berenang dan belajar memanah. Tidak saja dalam arti harfiah, tetapi beberapa pakar menerjemahkan mengendarai kuda adalah mengajarkan anak tentang skill of life yang artinya keterampilan dalam hidup jadi memberinya keterampilan atau keahlian. Berenang adalah pelajaran tentang survival of live, bagaimana mendidik anak agar selalu bersemangat, Tidak mudah menyerah dan tegar dalam menghadapi masalah. Kemudian memanah adalah mengajarkan anak untuk memiliki thinking of skill, yaitu dapat menentukan target dalam hidupnya. Karena setiap anak adalah unik, maka hargailah keunikannya. Biarkan anak menekuni hobi nya. Sebagai orang tua kita dapat membuka jalan ke masa depan anak dengan membantu mengembangkan minatnya dan menyusun rencana masa depannya. Dengan demikian diharapkan kemandiriannya akan terbangun dan yakinkan anak akan kemampuannya, sehingga anak tumbuh menjadi percaya diri. Belajar memanah seperti berlatih membangun thinking of skill, yaitu membangun kemandirian berpikir untuk menentukan dan meraih impian atau cita-citanya. Dan secara harfiah pun kegiatan mengendarai kuda, berenang dan memanah tersebut adalah kegiatan berolah raga yang bertujuan untuk melatih anak agar tumbuh menjadi anak yang berfisik kuat dan berjiwa sportif.

Dikatakan oleh Ali bin Abi Thalib RA. "Didiklah anak-anakmu sesuai dengan zamannya". Karena mereka bukan hidup di zaman mu dan sesungguhnya kalian diciptakan untuk zaman kalian. Jadi waktu terus berjalan dan terus berubah kita berharap agar mempunyai waktu yang baik lebih baik dari hari kemarin dan hari ini untuk hari esok, zaman terus berubah semakin canggih semakin di uji pula kehidupan dunia dan akhiratnya. Pendidikan pada anak dilalui dalam 3 tahap : 
a. Pada 7 tahun pertama, perlakukan anak sebagai raja untuk anak laki-laki dan ratu untuk anak perempuan dari umur (0-7 tahun). Maksudnya adalah bukan berarti kita harus dan wajib menuruti semua keinginan anak, akan tetapi harus memberikan perhatian yang sangat penuh kepada anak, karena di usia inilah mereka mengalami masa keemasan dan masa kejayaan. Saat memaksimalkan pembentukan sel otak $70 \%$, dan kemampuan anak menyerap informasi masih sangat kuat. Jangan serahkan berikan sepenuhnya pada pembantu, jangan berikan sepenuhnya pada nenek- kakeknya. Rawatlah mereka dengan tangan kita tangan orangtua. Perhatian kecil yang sederhana tapi tulus dari lubuk hati orangtua nya.

b. Pada 7 tahun kedua, perlakukan anak sebagai tawanan perang (7-14 tahun) Maksudnya adalah mulai mendisiplinkan anak tegas dalam kebaikan. Rasulullah SAW pun bersabda, untuk menyuruh anak-anak untuk shalat di umur 7 tahun, lalu memukulnya jika tidak shalat di umur 10 tahun. Pada fase kedua inilah akan terjadi pubertas. Anak harus dibekali nilainilai disiplin sebelum masuk ke masa pubertas dimana semua ketentuan rukun Islam (Shalat, Puasa, dll) harus ia lakukan sendiri dan akan menjadi dosa jika ia tinggalkan. Allah berfirman dalam Al-Qur'an surat Luqman ayat 17

"Wahai anakeku!!! Laksanakanlah sholat dan surublah (manusia) berbuat yang ma'ruf dan cegablah (mereka) dari yang mungkar dan bersabarlah terbadap apa yang menimpamu. Sesunggubnya yang demikian itu termasuk perkara yang penting. "(QS.Luqman : 17)(Departemen Agama RI, 2004)

c. Pada 7 tahun ketiga (14 tahun ke atas), perlakukan anak-anak layaknya sahabat kita sendiri ataupun teman curhat dan teman akrab. Di usia ini, anak bergulat dengan pencarian jati diri anak selalu ingin tau apa yang terjadi pada dirinya sendiri. Ia mengalami banyak peristiwa emosional dan sangat sensitif terhadap tubuhnya sendiri. contohnya mudah menangis, mudah marah, mudah bahagia, Ajak anak untuk sering berbagi cerita, curhat, dan ajak pula teman-temannya untuk akrab dengan kita dan berkawan dengan kita. Dengan begitu kita bisa mengawasi dan mengontrol anak tanpa harus mengekang tanpa harus memarahi anak. Dan jiwa jati diri anak akan terbentuk dengan baik karena adanya kepercayaan dari orang tua. 
Baryagis (2005) mengutip bahwa Muhammad Jamaluddin Mahfuzh mengungkapkan :

"Dalam Pendidikan Islam untuk anak dan remaja, membagi periode anak sebagai berikut :

1) Masa ayunan (2 tahun pertama sejak kelahiran)

2) Masa permulaan anak : 2-6 tahun

3) Masa akhir anak : 6-12 tahun

4) Masa menjelang remaja : 12-15 tahun

5) Masa remaja madya : 15-18 tahun

6) Masa remaja akhir : 18-22 tahun (Baryagis, 2005)

Pembagian periode anak didasarkan pada perkembangan gerak-geriknya anak, di tengarai tanda atau firasat dan contohnya :

a) Sebelum usia anak 2 tahun, anak belum mengetahui gerakan-gerakan bersifat reflek atau gerakan yang dilakukan tanpa sadar dan merupakan respon segera setelah adanya rangsangan.

b) Usia 2-4 tahun, anak sudah mampu mengerakan apa yang di inginkan seperti memukul-mukulkan pensil atau mainan.

c) Usia 4-7 tahun, mampu bergerak dengan cepat sebagai reaksi pikiranya terhadap rangsangan sesuatu di luar dirinya.

d) Usia 7-10 tahun, masa anak beradaptasi dengan lingkungan masyrakat sekitar ataupun di sekolah dan di rumah.

e) Usia 10-12 tahun, masa anak berinteraksi, anak mulai gemar berkelompok dan bekerjasama bersama teman nya.

f) Usia 12-14 tahun, masa awal pencarian jati diri, mulai mengetahui diri sendiri dan apa yang terjadi dengan dirinya sendiri.(Baryagis, 2005)

Periode masa kanak-kanak lebih mendesak dari kemampuan anak dalam membaca, menulis dan memahami. Beruntung itu adalah jenjang-jenjang usia anak dapat dikelompokkan dalam beberapa periode, yaitu antara lain:

a) Masa pratulis: 3-6 tahun (masa permulaan anak) Pada masa ini anak belum berbudaya tulis menulis. Ia baru sekedar gemar mendengarkan cerita. Anak akan bereaksi terhadap sesuatu yang melingkupnya. Ia bahkan cenderung meniru dan mengikuti gerak-gerik dan tindakan orang di 
sekitarnya. Daya pikir anak dalam usia ini sudah berfungsi, begitu pula daya khayalnya.

b) Masa Kedua: Masa awal baca tulis Masa ini umumnya berlangsung pada usia 6-8 tahun, terkadang mulai usia 5 tahun, dan berlangsung hingga usia 9 tahun, ini merupakan masa haus anak akan rasa ingin tahu. Apalagi khusus dalam lingkungan masyarakat (keluarga dan kehidupan intern). Pada masa ini anak sangat gemar bergaul (bermain), gemar dengan pengalaman baru bersama teman-temannya, mudah terpengaruh oleh sesuatu yang di lihat dan di dengarkanya. akan lebih baik jika anak mulai di latih berfikir tentang kehidupan dan alam semesta sekitarnya.

c) Masa ketiga: Masa aktif baca tulis (Lanjutan usia SD/MI) Masa ini berlangsung dalam rentang usia 8-12 tahun. Pada masa ini anak mulai gemar mencari identitas diri dan mencari perhatian, pamer kekuatan, egois dan berlagak sok bisa dalam banyak hal. Jika hal ini di sampaikan dengan cara yang tepat maka akan sangat berpengaruh bagi hidup, tindakan dan pikiran anak. Di antara cara yang tepat dalam hal ini ialah dengan mengajari anak menulis`sejarah atau biografi Rasulullah SAW yang memuat pesan-pesan dimaksud dari segi ucapan gaya, dan cara yang selaras dengan masa usia ini.

d) Masa Keempat: Masa Remaja (12-18 ) Dalam masa ini anak sudah menonjol dalam kemampuan memahami bahasa dan menggunakanya dengan bahasa yang lebih baik. Kemampuan bacanya bahkan sudah melampaui standar bisa dan biasa. Pada masa ini kepribadian anak cenderung suka kebebasan dan tidak ada beban tidak ada ancaman, suka pergaulan, dan membayangkan dirinya seakan tokoh hebat tokoh yang pintar cerdas dan kreatif. (Baryagis, 2005)

Perkembangan Sosial Dalam masa Buaian, Tahapan-Tahapan Pertumbuhan sosial pada Masa Buaian:

a) Bulan 3-5 anak mulai mengenal orang lain dan menangis apabila di tinggal sendirian.

b) Bulan 6-7 anak bisa membedakan suara bernada marah dan suara bernada tidak marah atau sedang sayang menyayangi dan lemah lembut.

c) Bulan 8-9 meniru orang lain secara sederhana, dengan cara itu mudah memahami dan menilai. 
d) Bulan 11-12 berhenti dari suatu perbuatan apabila di tegur orang dewasa, karena sudah mulai menyadari jika itu salah.

e) Bulan 18-20 anak mulai menampakan penentangan, menantang jika di salahkan atau tidak di beri penghargaan.

f) Bulan 20-23 perhatian anak beralih dan bermain bersama teman- teman .(Ahmad, 2005)

\section{Hadis tentang cara mendidik dengan keteladanan.}

Rasulullah SAW dalam mendidik para sahabat-sahabatnya dengan menggunakan macam-macam metode, salah satunya dengan menggunakan metode keteladanan, sehubunngan dengan hal ini ditemukan beberapa hadis yang cocok dan pas yang berkaitan dengan keteladanan, contohnya dapat dilihat dalam pengajaran kaifiyah sholat, bacaan sholat, kedisiplinan waktu dalam menegakkan shalat, dan membentuk ketekunan dalam bebribadah. (Umar, 2012)

a. Metode dengan keteladanan dalam pengajaran kaifiyah shalat.

Berkaitan dengan cara pegajaran kaifiyah shalat, terdapat hadis berikut :

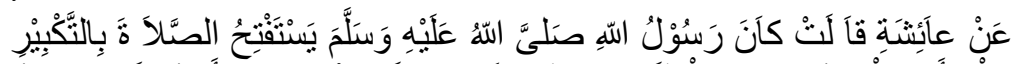

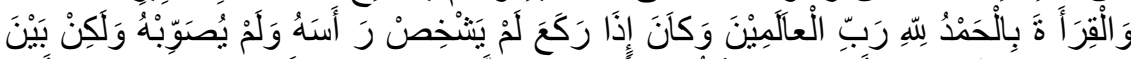

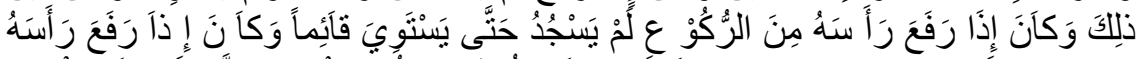

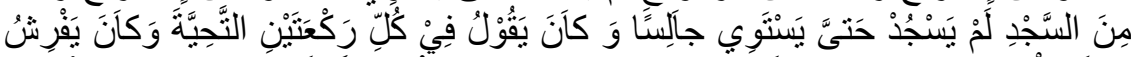

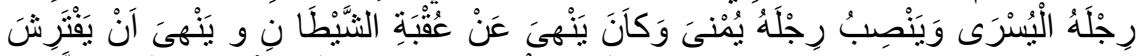

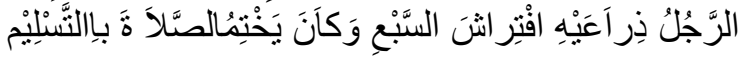

Sayyidah Aisyah RA berkata, "Rasulullah SAW memulai shalat dengan takbir dan memulai bacaan dengan al-hamdulillah rabb 'alamin. apabila Ruku' beliau tidak mendongakean kepalanya dan tidak pula menundukannya, tetapi diantara itu. Apabila bangkit dari ruku', beliau tidak. sujud sebelum berdiri betul-betul (lurus). Apabila mengangkat kepalanya dari sujud, beliau tidak sujud lagi bingga duduk betul-betul. Beliau membaca tahiyat ditiap-tiap rakaat, membentangkan kaki kirinya dan mendirikan kaki kanan. Beliau melarang uqbah asy-syaiton (cara duduk syetan, yaitu menghamparkan dua tapak kaki dan duduk diatas kedua tumitnya) dan melarang seseorang membentangkan dua lengannya (di bumi) sebagai bentangkan binatang buas. Selanjutnya beliau mengakhiri shalatnya dengan salam." (HR. Muslim).

Cara mendidik anak dengan menggunakan metode keteladanan dalam pengajaran kaifiyah shalat ini merupakan hal yang sangat cocok dan tepat. Hal ini dapat dipahami karena sesuai metode yang digunakan dengan kompetensi yang diharapkan dapat dimilki 
oleh anak didik dalam mendirikan shalat, umat islam diperintah untuk mengikuri cara yang dicontohkan Rasulullah SAW agar umat Islam dapat mengerjakannya, karena sudah sewajarnya beliau mampu memberikan contoh. Selain itu, hal tersebut agar dilaksanakan oleh para sahabat untuk mudah memahami dan tidak akan bisa melakukan kesalahan.(Umar, 2012)

b. Metode keteladanan dalam pengajaran bacaan shalat.

Sehubungan dengan penggunaan metode keteladanan dalam pengajaran bacaan shalat dikemukakan hadis berikut:

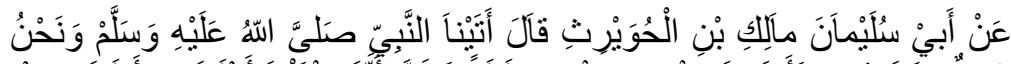

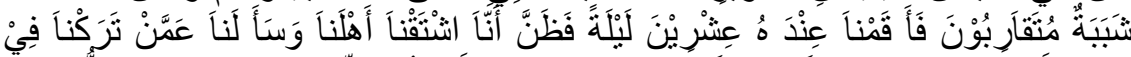

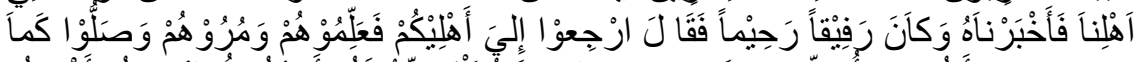

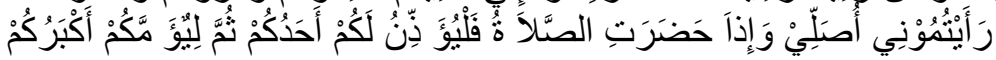

"Abu Sulaiman Malik bin Al-Huwairits berkata, "kami, beberapa orang pemuda sebaya mengungunjungi Nabi $S A W$, lalu kami menginap bersama beliau selama 20 malam. Belian menduga bahwa kami telah merindukan keluarga dan menanyakan apa yang kami tinggalkan pada keluarga, lalu kami memberitabukan kepada Nabi SAW. Beliau adalab orang yang halus perasaannya dan penyayang, lalu berkata "kembalilah kepada keluarga kalian. Ajarilah mereka, surublah mereka, dan shalatlab kalian sebagaimana kalian melihatku shalat, apabila waktu shalat telah masuk, bendaklah salah seorang dari kalian mengumandangkan adzan dan yang lebih tua hendaklah menjadi imam". (HR. Al-Bukhari dan Ad-Darimi).

Dalam hadis ini, Rasulullah SAW akan memberikan penekanan aataupun penegasan serta memberikan contoh karena adanya peniruan tentang bagaimana cara shalat sahabat kepada cara yang telah beliau perlihatkan sendiri. Hal tersebut berarti beliau sangat mengutamakan dan mengistimewakan metode keteladanan, karena metode keteladanan adalah metode yang mengajarkan orang lain untuk meniru ataupun mencoh hal-hal yang baik agar hasilnya pun baik.

c. Metode atau cara keteladanan dalam kedisplinan waktu pelaksanaan shalat.

Ibadah shalat fardu mempunyai waktu tertentu, setiap orang yang beragama Islam, setiap muslim dan muslimah harus melaksanakan shalat dengan tepat waktu, tunda semua pekerjaan ketika adzan sudah berkumandang. Apabila seseorang melaksanakan shalat diluar waktu, maka shalat tersebut dianggap tidak sah. Oleh karena itu, orang tersebut belum termasuk kedalam kategori orang yang belum memenuhi kewajiban. Namun jika ada orang yang 
terlambat dalam memenuhi kewajiban ini karena berbagai macam hal, termasuk karena sibuk dengan pekerjaan sehari-hari.

Rasulullah SAW telah menyampaikan tentang keteladanan dalam hal mengerjakan shalat yang tepat waktu. Beliau meninggalkan segala pekerjaannya ketika adzan dikumandangkan, dan yang sedang berkendara alangkah lebih baiknya berhenti terlebih dahulu. Informasi ini dapat dilihat dari hadis berikut:(Umar, 2012)

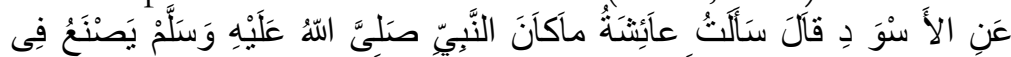

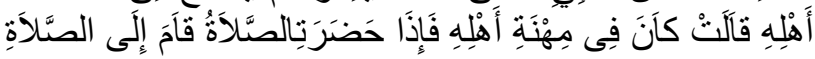

Al-Aswad meriwayatkan, "aku bertanya kepada Aisyah $\mathrm{RA}$, 'bagaimana keadaan Nabi SAW ketika bekerja?' Aisyah RA menjawab,' ketika beliau bekerja untuk urusan keluargannya, lalu masuk waktu shalat, maka beliau langsung keluar (berbenti bekerja) lalu shalat". (HR. AlBukhori)

d. Metode keteladanan dalam membentuk ketekunan mendirikan shalat.

Shalat adalah suatu ibadah yang harus dilakukan dan wajib dikerjakan dengan istiqomah dan terus menerus. Shalat dikerjakan jangan hanya ketika bagaikan kedatangan air banjir yaitu ketika bersemangat saja shalat dilakukan dengan terus menerus, tetapi saat kurang semangat mengerjakan kewajiban shalat akan mengalami penurunan dan malas akan ditinggalkan begitu saja. Rasulullah SAW telah memberikan keteladanan dalam mendirikan shalat termasuk shalat malam (tahajjud). Sehubungan dengan ini, terdapat hadis berikut.

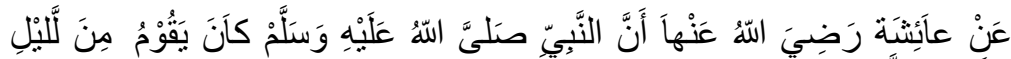

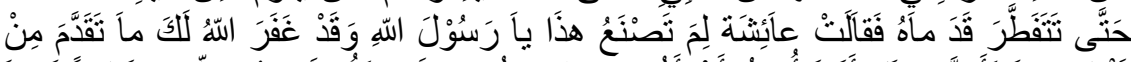

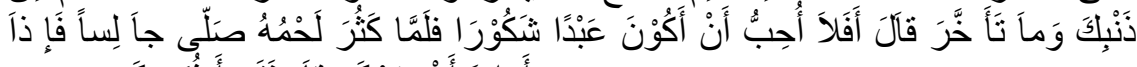

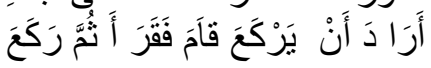

"Aisyah RA meriwayatkan babwa Nabi SAW mendirikan shalat pada waktu malam sehingga bengkak kedua kakinya, lalu Aisyah $\mathrm{R} A$ bertanya, "Ya Rasulullah, mengapa engkau mendirikan shalat sampai seperti ini? Padahal, Allah telah mengampuni dosamu yang telah lalu dan yang akan datang. "beliau menjawab, "apakah aku tidak ingin menjadi hamba yang bersyukur?" ketika badannya gemuk, beliau shalat dalam keadaan duduk. Apabila beliau bendak ruku' maka belian berdiri kemudian membaca beberapa ayat lalu ruku." (HR. Al-Bukhari). 
Dari hadis-hadis diatas dapat disimpulkan dan dipahami bahwa Rasulullah SAW telah mendidik umat dan para sahabatnya untuk mendirikan shalat dengan menggunakan metode keteladanan. Beliau menggunakan metode ini tentu dengan pertimbangan yang matang, untuk semua aspek pendidikan shalat, metode keteladanan ini dipandang sebagai suatu metode yang efektif dan efisien. Pandangan ini didukung oleh pendidikan modern.(Umar, 2012)

Manusia banyak belajar tentang berbagai macam kebiasaan yang baik dan tingkah laku yang baik dari kedua orang tua, guru, teman, dan saudara-saudaranya. Ia mulai belajar bahasa dengan meniru kedua orang tuanya dan saudara-saudaranya dengan mengucapkan kata-kata secara berulang kali. Tanpa terbiasa mendengarkan orang lain mengucapkan suatu kata, manusia tidak dapat berbahasa lisan.

\section{Hadis Tentang Pendidikan Karakter}

Hadis-hadis tentang Pendidikan Karakter Hadis-hadis tentang pendidikan karakter adalah hadis-hadis yang menyatakan hadis yang baik baik secara eksplisit (langsung) maupun implisit (tidak langsung), tentang penanaman nilai-nilai karakter pada diri seseorang, yang selanjutnya dapat diaplikasikan dalam kehidupan sehari-harinya baik di sosial dan kehidupan yang bermasyarakat, utamanya dalam proses pentransferan nilai-nilai karakter yang menjadi titik fokus penelitian ini. Di bawah ini akan dipaparkan redaksi hadis-hadis yang terkait dengan pendidikan karakter lengkap dengan sanad dan matannya. Adapun hadis-hadis yang penulis gunakan landasan adalah yang berkaitan dengan pendidikan karakter, antara lain:

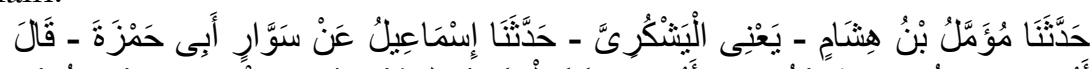

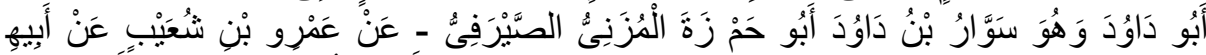

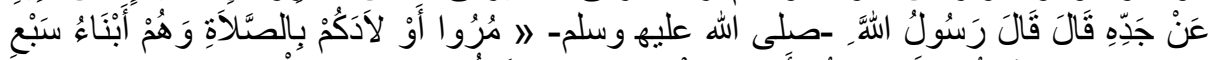

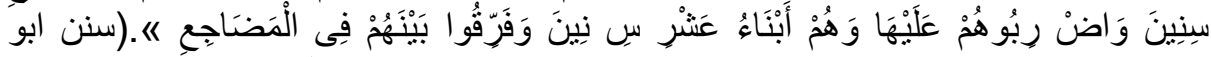

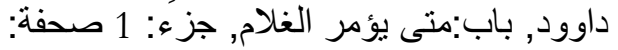

Hadis di atas menjelaskan tentang instruksi Rasulullah SAW kepada umat manusia yang bergama Islam agar memerintahkan anaknya untuk melaksanakan ibadah shalat ketika usia tujuh (7) tahun. Jika saat usia anak 10 tahun si anak tetap tidak mau melaksanakan ibadah shalat, maka orang tua boleh memukul anaknya tersebut dan itu merupakan sikap kasih sayang terhadap anak dan tegas dalam kebaikan. Pukulan yang dimaksud adalah pukulan yang bersifat mendidik ataupun tegas dengan menggunakan kasih sayang, agar si anak mau melakukan shalat. Pukulan yang dimaksud bukan pukulan untuk menyakiti, tetapi untuk mendidik 
anak agar memiliki karakter keimanan dan ketakwaan kepada Allah SWT. Rasulullah SAW mengajarkan kepada umat Islam agar dalam memberikan pendidikan kepada anak itu dilakukan secara bertahap. Pada usia 7 tahun anak sekedar diperintah untuk shalat, kalau tidak mau, tidak usah dipukul. Akan tetapi pada usia 10 tahun, ketika diperintah untuk shalat, anak tidak mau shalat, maka orang tua diperbolehkan untuk memukul anaknya pada bagian yang tidak membahayakan, misalnya, punggung; agar si anak mau melaksanakan shalat. Hadis yang memerintah shalat anak oleh orang tuanya sejalan dengan nilai-nilai karakter atau perilaku manusia terhadap Tuhan-Allah SWT. Nilai-nilai perilaku manusia terhadap Tuhan meliputi: taat kepada Tuhan, syukur, ikhlas, sabar, tawakkal (berserah diri kepada Tuhan). (Aprianif, 2017:203)

Nilai-nilai perilaku manusia terhadap Tuhan ini akan membentuk karakter spiritual atau keimanan atau ketakwaan kepada Allah SWT. Hadis tentang perintah shalat kepada anak juga mengandung nilai-nilai perilaku manusia terhadap diri sendiri. Nilai-nilai perilaku manusia terhadap diri sendiri mengandung karakter reflektif, percaya diri, rasional, logis, kritis, analitis, kreatif, inovatif, mandiri, hidup sehat, bertanggung jawab, cinta ilmu, sabar, berhati-hati, rela berkorban, pemberani, dapat dipercaya, jujur, menepati janji, adil, rendah hati, malu berbuat salah, pemaaf, berhati lembut, setia, bekerja keras, tekun, ulet atau gigih, teliti, berpikir positif, disiplin, antisipatif, inisiatif, visioner, bersahaja, bersemangat, dinamis, hemat, efisien, menghargai, dedikatif, pengendalian diri, produktif, ramah, cinta keindahan, sportif, tabah, terbuka, dan tertib.

Hadis tentang perintah shalat jelas mengandung -antara laintuntunan untuk mencapai kedisiplinan waktu, tanggung jawab sebagai hamba Allah SWT, berfikir positif, sabar dan tabah dalam menjalankan perintah Tuhan dan menjauhkan diri dari larangan Tuhan. Dalam menjalankan ibadah shalat, seseorang juga berarti melaksanakan refleksi diri dengan berkomunikasi langsung dengan Tuhan melalui ritual ibadah shalat. Hadis berikutnya yang mengandung konsep pendidikan karakter dapat dilihat di bawah ini:

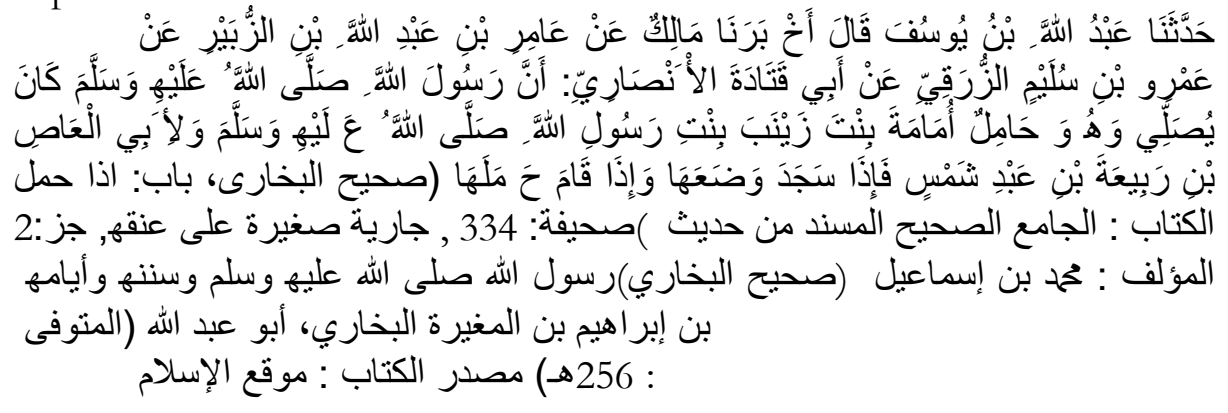


Hadis di atas memberikan penjelasan bahwa Rasulullah SAW pada suatu ketika- shalat dengan menggendong cucunya yang bernama Amamah binti Zainab binti Muhammad SAW. Pada waktu sujud, Rasulullah menaruh cucunya, dan pada waktu berdiri, Rasulullah menggendong cucunya tersebut. Hal ini menunjukkan sikap dan perilaku Rasulullah yang cinta dan sayang kepada anak, perempuan, dan 9 sesama. Perilaku ini memberikan teladan pembelajaran kepada umat Islam untuk supaya memiliki karakter cinta kepada sesama, kepada anak, dan kepada perempuan. Karakter cinta, peduli, kasih sayang ini sejalan dengan nilainilai perilaku manusia terhadap sesama manusia. Nilai-nilai perilaku manusia terhadap sesama manusia meliputi: taat peraturan, toleran, peduli, kooperatif, demokratis, apresiatif, santun, bertanggung jawab, menghormati orang lain, menyayangi orang lain, pemurah (dermawan), mengajak berbuat baik, berbaik sangka, empati dan konstruktif. Hadits di atas juga menunjukkan keberpihakan Rasulullah terhadap kaum perempuan. Pada masa Rasul sebelum diutus, hal yang paling menyedihkan adalah ketika kaum perempuan sangat dianggap hina dalam tradisi jahiliyah masa kebodohan yang belum hijrah. Kaum perempuan dianggap tidak ada harganya dan tidak begitu berguna. Fungsi perempuan hanya sebagai pemuas nafsu dan nafsu . Perempuan hanya sebagai ajang pelampiasan laki-laki. Tidak jarang ketika ada bayi perempuan terlahir, dikubur hidup-hidup karena dianggap tidak berguna untuk diajak perang. Posisi dan peran perempuan sangat dihinakan. Akan tetapi pada masa Rasulullah, posisi dan peran perempuan diangkat dan disetarakan dengan laki-laki. Hadis di atas menjadi salah satu hadis yang menunjukkan hal itu. Hadis berikutnya yang mengandung ajaran karakter kepada umat Islam adalah sebagai berikut:

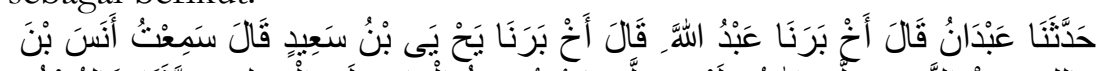

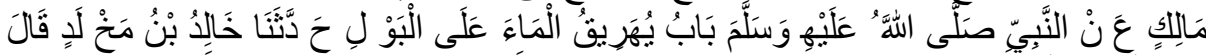

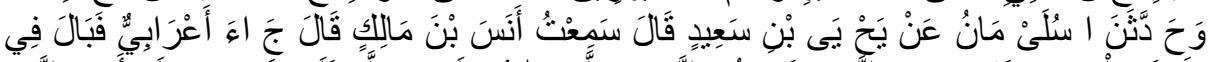

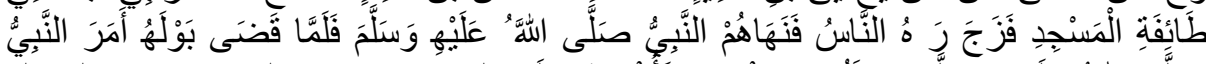

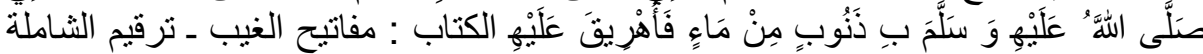

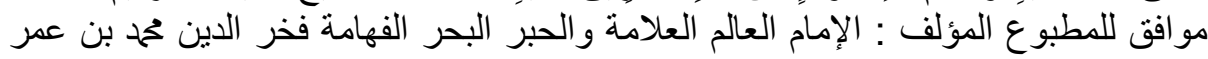

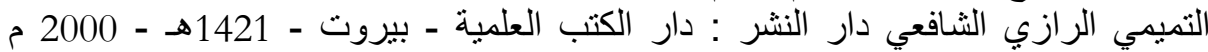

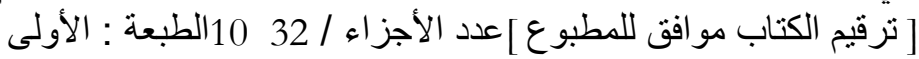

Hadis di atas menjelaskan bahwa suatu ketika ada seorang dari Arab (badui) non Muslim datang ke masjid lalu membuang air kecil di dalam masjid. Sahabat-sahabat marah dan emosi dan hampir memukuli orang tersebut, tetapi Rasulullah SAW melarang sahabat- sahabat yang ada di lokasi tersebut untuk menindak orang yang buang air kecil sembarangan tersebut. Rasulullah SAW menyuruh para sahabat agar membiarkan orang 
tersebut buang air kecil sampai selesai. Setelah orang tersebut menyelesaikan kencingnya, Rasulullah menyuruh para sahabat agar menyucikan ataupun membersihkan lantai masjid tersebut dengan air, dan kemudian memberikan teguran serta peringatan terhadap orang kafir tersebut. Perilaku Rasulullah di atas menunjukkan sikap toleran terhadap orang lain. Meskipun orang yang buang air kecil tersebut jelas-jelas salah, tetapi kesalahan tersebut dilakukan karena ketidaktahuan. Rasulullah sangat bijaksana dengan membiarkan orang yang buang air kecil tersebut untuk menuntaskan buang air kecilnya. Sebab ketika ditegur dan dimarahi pada waktu kencingnya belum selesai, sangat dimungkinkan orang tersebut lari ke mana-mana dan air kencingnya malah meluber ke manamana dan akan menjadi semakin memburuk. Di samping toleran, bijaksana, Rasulullah memberikan pelajaran kepada para sahabat, agar dalam memberikan sanksi kepada orang yang salah itu ketika orang tersebut berbuat kesalahan dengan kesengajaan padahal sudah mengetahui bahwa perbuatannya itu salah. Disamping perilaku Rasulullah di atas menunjukkan kandungan nilai karaktaer cinta kepada sesama manusia (antara lain toleran), juga menunjukkan nilai-nilai perilaku etik manusia terhadap lingkungan. Rasulullah sangat peduli terhadap lingkungan dan masyarakat, sehingga ketika suatu lingkungan kotor, sebisa mungkin kotoran itu tidak meluber ke lingkungan yang lain. Nilai-nilai perilaku manusia terhadap lingkungan meliputi: peduli dan bertanggung jawab terhadap pelestarian, pemeliharaan dan pemanfaatan tumbuhan, binatang dan lingkungan alam sekitar.

Tiga hadis di atas -dengan demikian- mengandung nilai-nilai karakter atau perilaku manusia terhadap Tuhan, perilaku manusia terhadap diri sendiri, perilaku manusia terhadap sesama manusia dan perilaku manusia terhadap lingkungan sekitar. Masih banyak hadits lain yang mengandung ajaran karakter yang dapat digali, namun dalam penelitian ini hanya tiga hadis yang disampaikan.

\section{Keteladanan Inti Dari Pendidikan}

Keberhasilan dalam proses sebuah pendidikan ditentukan oleh seberapa jenius, cerdas, pintar, otak setiap anak. Semakin ia jenius maka semakin dianggap sukses dan semakin di banggakan oleh kedua orangtuanya dan guru. Semakin ia meraih predikat juara kelas berturutturut, maka semakin sukseslah ia. Padahal, banyak anak didik yang sukses justru tidak mendapatkan prestasi gemilang di sekolahnya, seperti juara kelas, atau juara dalam mengikuti lomba di sekolah seperti cerdas cermat. Sebab kesuksesan tidak semua bertkaitan dengan kecerdasan otak saja. 
Akan tetapi, kesuksesan ternyata lebih ditentukan oleh kecakapan membangun hubungan dengan Tuhan Yang Maha Esa, diri sendiri, orang tua, guru, orang lain dan lingkungan masyarakat sekitar. Kecakapan membangun hubungan dengan tiga pilar (Tuhan, diri sendiri, dan sosial) tersebut merupakan ciri-ciri karakter yang dimiliki orang-orang sukses. Maka disinilah pentingnya pendidikan karakter pada anak.

Pendidikan karakter adalah pendidikan sepanjang hayat, terutama pembentukan karakter pada anak . sebagai proses perkembangan ke arah manusia yang sempurna atau kaffah. Oleh karena itu, pendidikan karakter sangat membutuhkan metode Modelling atau keteladanan, dimulai dari sentuhan ketika usia anak sejak dini sampai dewasa karena anak senang meniru, dan anak meniru jika orang tuanya bersikap baik, sopan santun dll.

Pendidikan karakter bukan hanya sekedar mengajarkan mana yang baik dan benar dan mana yang salah dan buruk. Bahkan lebih dari itu pendidikan karakter bisa dikatakan usaha untuk menanamkan kebiasaankebiasaan yang baik dan benar bukan kebiasaan atau contoh yang salah dan buruk.

Kenapa penting mempelajari pendidikan karakter sejak dini karena pendidikan Karakter adalah cara berfikir seseorang dan berperilaku yang menjadi ciri khas tiap orang untuk hidup dan bekerjasama, baik dalam lingkungan keluarga, masyarakat, sekolah bangsa, maupun negara.

Kenapa harus menggunakan Modelling dalam pembentukan karakter pada anak karena Komunikasi yang baik antara keluarga, guru dan masyarakat akan mempermudah dalam pengembangan karakter pada anak di rumah dan di sekolah.

a. Dalam vitalisasi peran keluarga dalam pembentukan karakter anak usia dini bisa menggunakan pendekatan maaqashid syariah yang membahas tentang melindungi agama, melindungi jiwa, melindungi akal, melindungi keturunan, dan melindungi harta. Cara kerjanya bersifat komulatif bukan alternative, kelima-limanya harus saling berkaitan dan harus terlindungi, jika ada yang tidak terlindungi maka sama aja 5 tersebut tidak terlindungi, jika tidak terlindungi maka kehidupan manusia akan musnah dan buruk. (Aprianif, 2017:39)

1) Hifdh an nas (melindungi keturunan) untuk melindunginya maka pernikahan harus sah, terdaftar di KUA, dan pernikahannya harus di publikasikan.

2) Cerdas dalam meilih jodoh : di nikahinya wanita karena ada 4 hal yaitu karena hartanya, karena kecantikannya, karena keturunannya, karena agamanya. Karena dari hal itu pernikahan tersebut bertujuan untuk melindungi anak, buah dari pernikahan adalah anak. 
3) Perkembangan manusia dan pembentukan karakter, terbagi menjadi 2 fase yaitu fase prenatal dan fase post natal. Dalam fase prenatal adanya sejak masa pembuahan di awali dengan doa yang baik agar terhindar dari sifat setan dan jin . adanya MOU dengan Allah SWT di usia 4 bulan, selalu terjaga kesehatannya, selalu berbuat baik dan bermanfaat untuk orang banyak dan berdoa ROBBI HABLI MIN AS-SHOLIHIN , ROBBANA HABLANA MIN AZWAJINA WADZURRIYYATINA QURROTA 'AYUN WAJ'ALNA LIL MUTTAQINA IMAMA. Dan pada fase post natal saat lahir di adzani, usia 7 bulan di berikan nama. Di aqiqahi, di sapih usia genap, mendidik dan di didik di sekolahkan agar cerdas, dan ketika sudah dewasa di nikahi bila sudah cukup syarat.

4) Hifdl aql melindungi akal ; untuk mempermudah mencapai tujuan apapun seperti di lembaga pendidikan,dan ada peran keluarga yang penting dalam keteladanan anak di rumah dan di sekolah, jika tidak ada pendidikan akan musnah binasa dan buruk manusianya.

5) Fungsi keluarga ada dalam segi ekonomi, sosial, edukatif, protektif, dan religious. Untuk segi ekonomi keluarga harus bisa membedakan mana yang halal dan haram baik dari segi harta dan makanan, untuk sosial memberikan pretise kepada anggotanya, untuk segi educator keluarga memberikan pendidikan kepada anak-anaknya, dalam segi protektif keluarga melindungi anggota keluarganya, dan yang terakhir dalam segi keagamaan keluarga memberikan ilmu agama yang baik dan benar karena peran keluarga sangat penting dalam memberikan agama seperti berinfaq, zakat, sholat, dan puasa.

b. Penerapan Metode Modelling Dalam Pendidikan Karakter Pada Anak

Dengan memberikan contoh contoh yang baik, karena anakanak adalah makhluk yang senang meniru dan otaknya sangat bekerja dengan cepat dalam merekam apa yang ia lihat, dan ia dengar.

Maka penerapannya ada 2 dilakukan di rumah dan di sekolah , pendidikan di rumah yang akan menjadi contoh / model / figure nya adalah orang-tua, dan pendidikan di sekolah yang menjadi contoh/ model/ figure nya adalah guru.

Pendidikan dalam keluarga adalah pendidikan pertama dan utama bagi anak, yang tidak bisa digantikan oleh lembaga pendidikan manapun. Karena pendidikan dalam keluarga yang menjadi tanggung jawab nya orang tua, dan pola asuh atau parenting style adalah salah satu faktor yang sangat berpengaruh dalam membentuk karakter anak dengan menggunakan metode modeling. 
Sebelum anak memasuki sekolah dan sudah diajarkan oleh orang-tuanya maka anak mempunyai perilaku yang positif bukan yang negatif, interaksi yang baik bukan yang buruk dengan gurunya, anak bisa percaya diri, anak dapat dan mampu berinteraksi sosial dengan temannya, dan anak termasuk memiliki kemampuan yang akademik.

Pendidikan karakter yang dilakukan di lingkungan sekolah, sekolah sangat menyadari pentingnya pendidikan karakter pada anak. Pendidikan karakter menjadi penting karena ia merupakan sebagai komponen utama dalam pendidikan dasar kita. Karena di dalam sekolah guru dapat mengaktifkan anak, anak tidak hanya mendengarkan dan menerima tugas dari guru, namun dapat meniru yang telah dimodelkan dan mengembangkan kreativitasnya. Kreativitasnya dari ide ide anak tersebut.

Peran orangtua dan guru adalah dengan memberikan contoh perilaku yang diinginkan untuk dapat ditiru dengan mudah oleh anak.

c. Dalam Situasi sosial-kultural masyarakat akhir-akhir ini semakin memburuk dan banyak kesalahan. Berbagai macam peristiwa yang merendahkan harkat dan martabat manusia berkembang di masyarakat bahkan dalam dunia pendidikan yaitu di sekolah, contohnya : hancurnya nilai-nilai moral, hancurnya nilai-nilai akademik, meningkatnya kenakalan remaja baik di dunia nyata dan dunia maya, sikap tidak etis terhadap guru, tidak hormat terhadap orang tua atau terhadap orang yang lebih tua.

Anak-anak mengalami krisis keteladanan. Hal ini terjadi karena, sedikitnya media masa yang mengangkat tema tentang tokoh-tokoh teladan bagi anak-anak. Beredarnya video yang tidak layak ditonton di Youtube, adanya video Tiktok yang tidak pantas gerakannya untuk diikuti, Tayangan-tayangan televisi misalnya didominasi acara hiburan dalam berbagai variasinya, acara sinetron atau film di bioskop, atau acara gosip selebriti yang tidak dapat diharapkan memberikan contoh kehidupan islami secara utuh. Dalam kondisi krisis keteladanan ini, pendidik menjadi basis penting. Oleh karenanya, pendidik harus memiliki kesadaran tinggi, untuk menjadi figur teladan dalam proses pembentukan akhlak Islami anak.

Ada beberapa kelebihan dan kekurangan dalam teknik pemodelan.

Kelebihannya : membuat anak menjadi percaya diri, mempunyai ide, dapat mengetahui keadaan yang sesungguhnya, dan membuat suasana belajar menjadi menyenangkan. 
Kekurangannya : harus mempunyai waktu yang banyak karena pembelajaran ini ada model ada yang mencontohkan da nada juga yang meniru.

Ada beberapa faktor yang menjadi penghambat dan pendukung dalam metode modelling dalam pembentukan karakter pada anak. Yang menjadi modelnya adalah orangtua dan guru, orang tua dirumah dan guru disekolah. Jadi peran orang tua dan guru sangatlah penting dalam proses pembentukan karakter pada anak. Untuk itu orang tua dan guru harus banyak belajar dan berhati-hati ketika memberikan contoh, maka berikanlah contoh yang baik bukan yang buruk, karena anak itu senang meniru.

Contoh : ibu minum sambil duduk maka anak langsung meniru minum sambil duduk.

Jika ibu mencontohkan minum sambil berdiri maka anakpun akan melakukan hal yang sama.

Kelebihannya jika sedang disekolah proses belajar mengajar, membuat anak menjadi berani dan percaya diri, bagi guru mempermudah dalam proses pembelajaran dan mempermudah anak dalam memahami pelajaran tersebut.

Contohnya: dalam matapelajaran Fiqh praktek sholat, guru mencontohkannya terlebih dahulu, kemudian anak memahami dilanjutkan anak langsung mempraktikkannya sendiri. Atau guru mempraktikkan dan anak langsung mengikuti nya.

Contoh lain : dalam matapelajaran seni budaya membuat prakarya dari tanah liat, guru mencontohkan cara membuatnya terlebih dahulu. Kemudian anak menjadi percaya diri untuk membuat lebih bagus dan lebih berkreasi.

d. Analisis Surat Al-Ahzab ayat 21 Menurut (Muhammad Mutawali Al Sya'rawi dan Muhammad Quraish Shihab)

Muhammad Mutawali Asy-Sya'rawi Di dalam kitabnya AsySya'rawi memaparkan bahwa Allah SWT memuji kepada Nabi Muhammad SAW. Beliau memaparkan bahwa teladan insani yang baik, tertinggi dan termulia ialah Muhammad bin Abdullah, Rasulullah SAW.

Rasulullah SAW selain sebagai seorang Rasul, seorang Nabi, tapi adalah seseorang yang sangat istimewa, karena Rasulullah mempunyai akhlak yang baik sehingga umatnya sangat cinta kepadanya dan menjadikan Rasulullah sosok suri tauladan yang cocok untuk menjadi contoh yang baik bukan yang buruk dan model dalam pembentukan karakter anak sejak dini yang di terapkan oleh orang tua di rumah dan oleh guru di sekolah. 
Dapat penulis simpulkan menurut Imam sya'rawi : ayat tersebut jelas disebutkan kata uswah dan hasanah yang berarti teladan yang baik. Maka dapat dipahami bahwa konsep keteladanan sudah lama ada dan diberikan oleh Allah SWT. dengan cara mengutus para Rasul, terutama Nabi Muhammad SAW. tujuannya untuk menjadi panutan bagi umat Islam. Begitu halnya dengan seorang guru harus menjadi panutan atau teladan yang baik bagi anak didiknya di sekolah, dan seorang orang tua harus menjadi panutan yang baik bagi anak-anaknya di rumah.

Mengenai pembentukan karakter pribadi anak, Imam Sya'rawi berkata, "Yang terpenting dalam membentuk pribadi anak adalah suri teladan. Seandainya didapatkan suri teladan yang baik, seorang anak akan menjadikannya sebagai contoh. Maka seorang anak harus dicermati dengan baik, dan di sana terdapat perbedaan antara mengajari anak dan membentuknya.

Dalam proses mengajari dan membentuk pendidikan karakter dengan menggunakan metode modelling tujuannya untuk memperbaiki perilaku manusia, terutama perilaku anak-anak menjadi baik dan tidak ada yang buruk. Perilaku seorang Muslim yang baik idealnya haruslah bersumber dari ajaran-ajaran agama Islam yang dibawa oleh Nabi Muhammad SAW.

Sehingga dengan akhlak manusia dapat lebih mengutamakan kebaikan, senang kepada kebaikan, kebenaran dan senang dalam kebenaran, kemudian dibentuk dan dilatih untuk mencintai yang terpuji dan membenci yang tercela, maka sifat-sifat tersebut dapat menjadi karakter bagi jiwa manusia terutama anak-anak, sehingga perbuatanperbuatan positif dan sikap-sikap terpuji ini adalah apa yang dikenal dengan akhlak yang baik.

Menurut Muhammad Quraish Shihab Jadi, tujuan dari diturunkannya surat Al-Ahzab khususnya ayat 21 adalah untuk memberikan kabar gembira dan hiburan kepada Rasulullah SAW beserta kaum mu'minin saat menghadapi berbagai rintangan, siksaan dan celaan yang dilancarkan oleh musuh Allah, dimana ujian tersebut tidak hanya menimpa mereka saja namun juga para Rasul dan nabi sebelum mereka. Sebagaimana surat ini juga untuk meneguhkan dan memperkuat dalil akan kebenaran risalah yang diemban oleh Rasulullah SAW.

Dalam Tafsir Al-Mishbahnya Muhammad Quraish Shihab berbicara tentang orang-orang yang munafik mengaku memeluk Islam, tetapi tidak mencerminkan ajaran Islam. Seakan-akan ayat itu mengatakan: "Kamu telah melakukan aneka kedurhakaan, padahal 
sesungguhnya di tengah kamu semua ada Nabi Muhammad yang mestinya kamu teladani”. Jadi tidak menganggap penting tentang suri tauladan, hidup semaunya saja tanpa mengikuti ajaran Nabi, dan hanya mementingkan hal duniawi saja bukan akhirat. dan di dalam tafsirnya ada empat tipe manusia, yaitu pemikir, pekerja, seniman, dan jiwanya larut di dalam ibadah. Jika Berkumpulnya keempat tipe manusia itu dalam kepribadian Rasul SAW, dimaksudkan agar seluruh manusia meneladani sifat-sifat terpuji yang ada pada diri Rasul SAW. Agar hidup kita semakin berkah baik di dunia dan di akhirat.)

\section{SIMPULAN}

Sebagai bagian dari akhir skripsi ini, penulis kemukakan dari hasil pembahasan tentang "Metode modelling dalam proses pendidikan karakter pada anak (analisis surat Al-Ahzab ayat 21)", maka dapat disimpulkan :

1. Bahwa sistem dan penerapan metode modelling dalam pembentukan karakter anak itu sangat dipengaruhi oleh pihak yang memiliki otoritas baik di rumah maupun di sekolah. Peran orang tua merupakan aspek yang paling berpengaruh dalam pembentukan karakter di rumah. Peran guru merupakan aspek yang paling berpengaruh dalam pembentukan karakter di sekolah.

Rasulullah SAW adalah suri tauladan kita semua. Kita wajib meneladaninya agar kita dapat mengaplikasikannya ke anak contoh yang baik, akhlak yang baik, seperti Rasulullah SAW. Bukan contoh yang buruk dan akhlak yang buruk.

2. Ada beberapa faktor yang menjadi penghambat dan pendukung metode modelling dalam pembentukan karakter pada anak. Faktor pendukungnya adalah : membuat anak menjadi percaya diri, mempunyai ide, dapat mengetahui keadaan yang sesungguhnya, dan membuat suasana belajar menjadi menyenangkan. Faktor penghambatnya adalah : harus mempunyai waktu yang banyak karena pembelajaran ini ada model ada yang mencontohkan dan ada juga yang meniru. 


\section{DAFTAR PUSTAKA}

Ahmad, K. asy syantut. (2005). Rumah Pilar Utama pendidikan Anak. Robbani press 2005.

Al-Jaza'iri, A. B. J. (2008). Pedoman Hidup Muslim. terj. Hasanuddin dan Didin Hafidhuddin. PT Pustaka Litera Antar Nusa.

al-Nahlawi, A. (1989). prinsip-prinsip dan metode pendidikan Islam, terj. Noer Ali. Darul Fijr.

Aprianif. (2017). Pandangan Hukum Islam Terhadap Dewasa Dini. Cinta Buku Media.

Arifin, A. S. (2017). MELALUI METODE KETELADANAN DI SMK MA ' ARIF NU 1 SUMPIUH KECAMATAN SUMPIUH KABUPATEN BANYUMAS FAKULTAS TARBIYAH DAN ILMU KEGURUAN INSTITUT AGAMA ISLAM NEGERI ( IAIN ) PURWOKERTO.

Asmani, J. M. (2011). buku panduan internalisasi pendidikan karakter di sekolah. Diva Press.

Asy-Sya'rawi, M. M. (1999). Tafsir asy-Sya'rawi (Jilid 19). Akhbar AlYaum.

aunillah, nurla isna. (2011). Panduan Menerapkan pendidikan Karakter di sekolah. Laksana.

Azwar, S. (2009). Metode Penelitian. Pustaka Pelajar.

Bafirman. (2016). Pembentukan Karakter siswa melalui pelajaran penjasorkes. Kencana.Bandura, A. (1977). Social Learning Theory. New Jersey.

Barsihannor. (2009). Belajar dari Lukman al - Hakim (Muhammad R). Kota Kembang.

Baryagis, H. (2005). Wahai Ummi Selamatkan Anakmu. Arina.

Departemen Agama Republik Indonesia. (2003). Al-Qur" an Terjemah. al hidayah.

Departemen Agama Republik Indonesia. (2012). Al Qur'an dan Terjemahnya. Sukses Publishing.

Departemen Agama RI. (2004). Al - Qur'an dan terjemahnya. Al Qur'an 2004.

E. Baharuddin. (2014). Books @ Books.Google.Co.Id. In Journal Ekonomi dan Bisnis Indonesia (Vol. 23, p. 187).

https://books.google.co.id/books?id=t3zPqTnRjX0C\&dq=wrong + diet + pills\&source $=$ gbs_navlinks_s

fatah, abdul. (2009). 40 Metode Pendidikan dan Pengajaran Rasulullah $S A W$. Isyad Baitus Salam.

Fathani, A. H. (2008). Ensiklopedi Hikmah Memetik Buah Kehidupan Di Kebun Hikmah. darul hikmah. 
Gregory J. Feist, J. F. (2008). Theories of Personality. Pustaka Pelajar.

Gunawan heri. (2014). Pendidikan Karakter Konsep Dan Implementasi. alfabeta.

Hariyati, N. (2011). Pengembangan Kurikulum Pendidikan Islam. Alfabeta. Abadi.

Hidayat, R. (2015). Mubammad Saw The Super Teacher. Zaytuna Ufuk

hisyam, ibnu. (n.d.). sirah nabawiyah ibnu hisyam jilid 2. darul falah. Sya'rawi.

Idit, midi muhammad. (2014). Biografi Syaikh M. Mutawalli asy-

Kamsinah. (2014). Tugas dan tanggung jawab guru dalam pendidikan islam (Nur khalis). Alauddin university pers.

Kartini, K. (1990). Pengantar Metodologi Riset Social. Mandar Maju.

kementrian pendidikan nasional (kemendiknas). (2010). Grand Desain Pendidikan Karakter.

Koesoema, A. doni. (2010). pendidikan karakter strategi mendidik anak di zaman global. Grasindo.

Muhammad, H. (2006). Tokoh-Tokob Islam yang Berpengaruh Abad 20. Gema Insani Press, 2006.

Munir, A. (2006). Spritual Teaching. Pustaka Insan Madani.

Mustofa, A. (2019). Metode Keteladanan Perspektif Pendidikan Islam. CENDEKIA: Jurnal Studi Keislaman, 5(1). https://doi.org/10.37348/cendekia.v5i1.71

Narvaez, D. \& Lapsley, D. K. (2008). Teaching moral character. For Teacher Education. The Teacher Educator, 43(2), 156-172.

Nata, A. (1997). Filsafat Pendidkan Islam. logos wacana ilmu.

Nata, A. (2005). Tokoh- tokoh Pembaharuan Pendidikan Islam di Indonesia. RajaGrafindo Persada.

Nurhadi, G. S. A. (2003). Pembelajaran Kontekstual (Contextual Teaching And Learning/CTL) Dan Penerapannya Dalam KBK. Penerbit Universitas Universitas Negeri Malang.

Nuryatin, A. (2010). Mengabadikan Pengalaman dalam Cerpen. Yayasan Adhigama.

Padil, M. dan T. S. (2010). Sosiologi Pendidikan, Keluarga, Masyarakat dan Sekolah. UINMaliki Press.

Pendidikan, Departemen, dan K. (1995). Kamus Besar Bahasa Indonesia (kedua cet). Balai Pustaka.

Rahman, J. 'Abdur. (2005). Tahapan Mendidik Anak Teladan Rasulullah, terj. Babrun Abubakar Ibsan Zubaidi. Irsyad Baitus Salam.

ramayulis. (2010). Metodologi Pendidikan Agama Islam . kalam mulia. 
Samani, muchlas \& hariyanto. (2011). konsep dan model pendidikan karakter. PT Remaja Rosdakarya.

Shihab, Quraish, M. (1992). Membumikan al-Qur'an. Mizan.

Shihab, M., \& Quraish. (2002). Tafsir Al-Misbah, Pesan, Kesan dan keserasian al-Qur'an. volume 11, 213.

Sholeh, A. rahman. (2005). Pendidikan Agama dan Pengembangn untuk Bangsa. PT. Raja Grafindo Persada.

Sugiyono. (2007). Metode Penelitian Kuantitatif, Kualitatif, dan R \& D. Alfabeta.

Suharsimi, A. (1998). Prosedur Penelitian Suatu Pendekatan Praktek. Rineka Cipta.

Suhono, S., \& Utama, F. (2017). Keteladanan Orang Tua dan Guru dalam Pertumbuhan dan JMKSP. Jurnal Manajemen, Kepemimpinan, Dan Supervisi Pendidikan, Dan Jurnal Ilmiah Pendidikan Dasar, Volume 3,.

Sutrisno, H. (1985). Metodologi Research. (Yogyakarta: Yayasan Penerbit Fakultas Psikologi UGM.

Suwardi, E. (2011). Metodologi Penelitian Sastra. Tim Redaksi CAPS.

Syamsudin Nor \& Achmad Sunarto. (2005). Himpunan Hadits Shabih Bukhori. AnNur Press.

Taha, H. A. (1992). Operation Research-An Introduction. Macmillan Publishing Company, 1-10.

Uhbiyati, N. (1999). ilmu pendidikan islam II. Cv Pustaka Setia.

Umar, B. (2012). Hadits Tarbawi. Amzah.

Wahiduddin Khan maulana. (2016). Mubammad Nabi Untuk Semua. pustaka alfabet.

Wibowo, A. (2012). Pendidikan Karakter: Strategi Membangun Karakter Bangsa Berperadaban. Экономика Региона.

Zainudin. (2013). Pendidikan Anak Sebagai Tuntutan Masa Depan Anak. Ta'allum Jurnal Pendidikan Islam, 01. $n$. 